\title{
Infrastructure Sharing for Acceleration of Economic Equality in Indonesia Islands Regions
}

\author{
Ade Marsinta Arsani ${ }^{1}$ \\ M. Arif Kurniawan ${ }^{2}$ \\ Statistics Indonesia
}

\begin{abstract}
Indonesia in general is an archipelagic country, but only eight provinces specifically have island characteristics, this is indicated by the comparison of land and sea area and the presence of islands. The big difference in the characteristics between the island province with the provincial non archipelago cause differences in the solution to any problems encountered. One of the problems faced by island provinces is the slow distribution of goods which results in the difficulty of production competitiveness, the decline in the quality of goods consumed by the people and the price disparity felt by the people in the islands. The existence of sea tolls has not been utilized optimally especially by island provinces in the eastern region of Indonesia. This study aims to outline solutions to overcome problems related to goods distribution and accelerate economic equality in island provinces, especially those located in eastern Indonesia. The method used in this study is a description and analysis of exploration. Some of the solutions outlined are the utilization of the sea tolls and cooperation with pioneering shipping to build special supply chains, map the potential of the region, and develop potential centers. In addition to the sea toll, Bulog's role as an institution that can support distribution and warehousing is also sharpened. As a supporter of transactions and distribution, the role of PT Pos Indonesia and cooperatives was also considered. Both institutions can act as financial intermediary services related to joint accounts, savings and loans, and guaranteed transactions. This is done so that the potential of all levels of society can be maximized. Furthermore, the role of the regional government as a policy regulator also has a role in the use of infrastructure sharing.
\end{abstract}

Keywords: infrastructure sharing, supply chain, equality, islands development.

\footnotetext{
${ }^{1}$ Ade Marsinta Arsani is a Statistician at the Directorate of Expenditure Account - BPS. E-mail address: ademarsinta@ gmail.com.

${ }^{2}$ M. Arif Kurniawan is a Head of Consolidation of Regional Expenditure Account - BPS.
} 


\section{Pemanfaatan Infrastructure Sharing Untuk Percepatan Pemerataan Ekonomi Wilayah Kepulauan di Indonesia}

Ade Marsinta Arsani dan M. Arif Kurniawan

\section{Pendahuluan}

\subsection{Latar Belakang}

Berdasarkan data yang dikeluarkan oleh Pusat Hidrografi dan Oseanografi Angkatan Laut (Pushidrosal) pada bulan Juni 2017, jumlah keseluruhan pulau di Indonesia mencapai 17.500 pulau yang terbagi habis menjadi 34 provinsi. Namun, hanya 8 provinsi yang berstatus sebagai Provinsi Kepulauan. Menurut UU Nomor 23 Tahun 2014 () tentang Pemerintahan Daerah, daerah provinsi yang berciri kepulauan adalah daerah provinsi yang memiliki karakteristik secara geografis dengan wilayah lautan lebih luas dari daratan yang di dalamnya terdapat pulau-pulau yang membentuk gugusan pulau sehingga menjadi satu kesatuan geografis dan sosial budaya. Berdasarkan definisi tersebut, wilayah yang termasuk Provinsi Kepulauan adalah Kepulauan Bangka Belitung, Kepulauan Riau, Nusa Tenggara Barat, Nusa Tenggara Timur, Sulawesi Utara, Sulawesi Tenggara, Maluku, dan Maluku Utara. Perbedaan kondisi geografis tentu akan berdampak terhadap banyak aspek, termasuk aspek sosial ekonomi. Kondisi geografis yang relatif lebih sulit dibanding provinsi yang tidak berciri kepulauan mengakibatkan terbatasnya sarana dan prasarana perhubungan, pendidikan, kesehatan, air bersih, ekonomi, sosial budaya, hukum, keamanan, dan ketertiban, telah membuat masyarakat di Provinsi Kepulauan atau berciri kepulauan ini hidup bergantung pada kearifan lokal mereka masing-masing dari generasi ke generasi (Kuahaty 2017). Kondisi geografis Provinsi Kepulauan ini menciptakan komunitas-komunitas di provinsi kepulauan tersegregasi dalam pemukiman menurut teritorial suatu pulau, sehingga berimplikasi pada kuatnya rasa keterikatan pada tanah (pulau) serta menciptakan pola hidup di pulau-pulau kecil selaras dgn alam dan relatif lamban menerima perubahan.

Dari sisi ekonomi dan sosial, jika dilihat dari data PDRB 2011-2017, hampir semua Provinsi Kepulauan mengalami perlambatan pertumbuhan ekonomi seiring dengan perlambatan pertumbuhan ekonomi nasional. Namun demikian, sebagian besar Provinsi Kepulauan masih tumbuh di atas pertumbuhan ekonomi nasional. Sinyal positif pertumbuhan ekonomi ini sayangnya tidak diikuti dengan tingkat pemerataan ekonomi. Angka Gini Ratio yang dirilis oleh Badan Pusat Statistik menunjukkan bahwa sebagian besar Provinsi Kepulauan mengalami peningkatan kesenjangan pada semester II 2017. Masalah lain yang dialami oleh Provinsi Kepulauan juga ditunjukkan oleh indikator Indeks Pembangunan Manusia (IPM). Kecuali Kepulauan Riau dan Sulawesi Utara, Provinsi Kepulauan lainnya masih memiliki angka IPM di bawah nilai rata-rata IPM nasional. Hal ini menandakan bahwa kondisi sumberdaya manusia di Provinsi Kepulauan tergolong masih rendah.

Salah satu hal yang diduga menyebabkan lambatnya perkembangan Provinsi Kepulauan ini adalah karena aktivitas, jenis, dan derajat dinamika ekonomi umumnya terbatas dan berskala kecil, serta belum didukung oleh jaringan distribusi dan pemasaran secara memadai. Pemerintah sudah melakukan beberapa upaya untuk mempercepat pemerataan ekonomi di seluruh Indonesia termasuk di Provinsi Kepulauan. Hal ini termuat 
dalam misi ke 7 Rancangan Pembangunan Jangka Panjang Nasional 2005-2025 (RPJPN 2005-2025) yang menyebutkan: Mewujudkan Indonesia menjadi negara kepulauan yang mandiri, maju, kuat, dan berbasiskan kepentingan nasional. Salah satu program prioritas yang dilakukan oleh pemerintah adalah pembangunan dan optimalisasi tol laut. Tol laut bertujuan untuk mengintegrasikan pengembangan wilayah serta menyeimbangkan perekonomian (pertumbuhan dan disparitas harga) KBI dan KTI melalui pengembangan kawasan dengan dukungan Tol Laut (Bappenas, 2017). Beberapa upaya dan peraturan juga sudah dibuat untuk mengoptimalisasi kinerja tol laut, salah satunya adalah pembangunan konektivitas pelabuhan strategis tol laut serta pemberian subsidi angkutan barang pada pelabuhan nonkomersil yang dilalui oleh tol laut.

Sayangnya, program ini belum memberikan dampak optimal pemerataan ekonomi di Provinsi Kepulauan, terutama Provinsi Kepulauan yang terletak di Indonesia Timur. Misi tol laut yaitu : Ship Follow The Trade and Ship Promote The Trade belum berjalan optimal. Distribusi barang hanya terjadi satu arah, dari pulau Jawa ke bagian Indonesia Timur yang mengangkut bahan pokok, namun rute sebaliknya kapal jaringan tol laut belum mengangkut hasil bumi dari Indonesia Timur untuk meningkatkan pendapatan penduduk. Menurut Plt Dirjen Perhubungan Laut Kemenhub, Bay Hasani, masalah yang terjadi pada kapal tol laut saat ini adalah masih banyaknya muatan kosong, begitu kapal tol laut balik dari pelabuhan terpencil menuju Surabaya atau Jakarta (Detik.com, 2017).

\subsection{Identifikasi Masalah}

Guna mencari pemecahan masalah lambatnya pemerataan ekonomi di Provinsi Kepulauan, maka identifikasi masalah terlebih dahulu wajib dilakukan. Karakteristik yang paling menonjol dari Provinsi Kepulauan adalah kondisi geografis yang relatif berbeda dengan wilayah lain di Indonesia. Kondisi ini secara langsung maupun tidak langsung berdampak terhadap berbagai aspek, utamanya aspek ekonomi. Permasalahan pada aspek ekonomi menjadi sumber utama terjadinya kesenjangan.

\section{Gambar 1. Identifikasi Masalah Pemerataan Ekonomi di Provinsi Kepulauan}
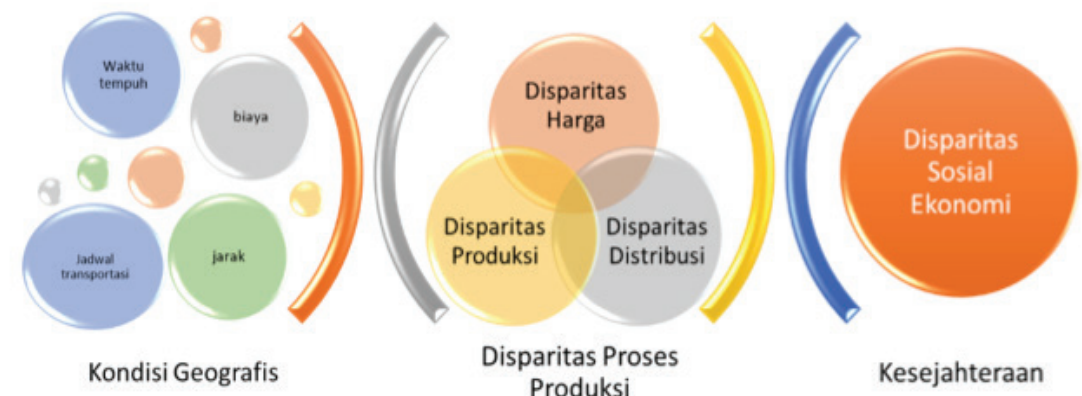

Salah satu langkah yang telah ditempuh oleh pemerintah adalah program tol laut. Namun, program ini belum optimal karena tol laut baru menjangkau pusat-pusat ekonomi, umumnya berupa pelabuhan besar, di Provinsi Kepulauan. Ketimpangan akan semakin terasa karena bagian lain provinsi kepulauan belum terjangkau oleh program tol laut sehingga disparitas masih tetap terasa. Selain itu, adanya tol laut belum secara optimal meningkatkan pertumbuhan ekonomi, karena kapal hanya mengangkut barang konsumsi (dan sedikit 
barang modal) dari Pulau Jawa, belum mengangkut balik bahan baku dan hasil produksi ke Pulau Jawa dan sekitarnya. Oleh karena itu, diperlukan optimalisasi kembali program tol laut yang disinergikan dengan program-program lainnya untuk mempercepat pemerataan ekonomi di Provinsi Kepulauan guna mencegah dan mengatasi kesenjangan. Program yang akan disinergikan dengan program tol laut ini diharapkan dapat melibatkan berbagai lapisan masyarakat dan instansi pemerintah sehingga sense of belonging program-program ini lebih terasa dan manfaatnya dapat dirasakan oleh pihak luas.

\section{Metodologi}

Metodologi yang dipergunakan dalam penelitian ini adalah metode analisis deskriptif, dan exploratory analysis. Analisis deskriptif dipergunakan untuk mengetahui gambaran umum, karakteristik, serta menganalisis masalah dasar Provinsi Kepulauan. Sementara, exploratory analysis dipergunakan untuk menganalisis masalah lebih dalam serta mencari kebijakan yang tepat untuk pemecahan masalah yang terjadi.

Penelitian ini mempergunakan data Sensus Pertanian 2013, Sensus Potensi Desa 2014, Survei Sosial Ekonomi Nasional 2015, serta beberapa indikator sosial ekonomi seperti IPM, kemiskinan dan gini ratio. Studi pustaka juga dilakukan untuk pendalaman masalah dan perumusan kebijakan.

\section{Hasil dan Pembahasan}

\subsection{Uraian Kondisi Umum Provinsi Kepulauan}

Tabel 1. Pertumbuhan Ekonomi Provinsi Kepulauan 2013-2017

\begin{tabular}{|l|c|c|c|c|c|}
\hline \multirow{2}{*}{ Provinsi (PDRB) } & \multicolumn{5}{c|}{ Pertumbuhan Ekonomi } \\
\cline { 2 - 6 } & 2013 & 2014 & 2015 & 2016 & 2017 \\
\hline Kep. Bangka Belitung & 5.2 & 4.67 & 4.08 & 4.11 & 4.51 \\
\hline Kep. Riau & 7.21 & 6.6 & 6.02 & 5.02 & 2.01 \\
\hline Nusa Tenggara Barat & 5.16 & 5.17 & 21.76 & 5.82 & 0.11 \\
\hline Nusa Tenggara Timur & 5.41 & 5.05 & 4.92 & 5.17 & 5.16 \\
\hline Sulawesi Utara & 6.38 & 6.31 & 6.12 & 6.17 & 6.32 \\
\hline Sulawesi Tenggara & 7.5 & 6.26 & 6.88 & 6.51 & 6.81 \\
\hline Maluku & 6.38 & 6.31 & 6.12 & 6.17 & 6.32 \\
\hline Maluku Utara & 9.59 & 5.07 & 15.5 & 9.98 & 7.14 \\
\hline Indonesia & 5.56 & 5.01 & 4.88 & 5.03 & 5.07 \\
\hline
\end{tabular}

Sumber: Badan Pusat Statistik (diolah)

Mayoritas pertumbuhan ekonomi Provinsi Kepulauan mengalami penurunan dalam 5 tahun terakhir seiring dengan penurunan pertumbuhan ekonomi nasional. Hampir seluruh Provinsi Kepulauan tumbuh di atas pertumbuhan ekonomi nasional pada tahun 2016. Jika dilihat dari struktur PDRB masing-masing Provinsi Kepulauan, sebagian komponen mempunyai peranan yang relatif tetap, sementara komponen lain cenderung fluktuatif. Komponen dengan peranan relatif stabil dapat dijadikan peluang untuk memicu pertumbuhan ekonomi provinsi tersebut. 
Tabel 2. Pertumbuhan Ekonomi dan Share Net Ekspor 2016 dan 2017

\begin{tabular}{|c|c|c|c|c|}
\hline \multirow{2}{*}{ Provinsi } & \multicolumn{2}{|c|}{ Pertumbuhan Ekonomi } & \multicolumn{2}{|c|}{ Share Net Ekspor } \\
\hline & 2016 & 2017 & 2016 & 2017 \\
\hline Kepulauan Bangka Belitung & 4.11 & 4.51 & -35.22 & -54.53 \\
\hline Kepulauan Riau & 5.02 & 2.01 & 12.31 & 10.11 \\
\hline Nusa Tenggara Barat & 5.82 & 0.11 & -13.96 & -14.49 \\
\hline Nusa Tenggara Timur & 5.17 & 5.16 & -48.51 & -49.28 \\
\hline Sulawesi Utara & 6.17 & 6.32 & 1.01 & 0.77 \\
\hline Sulawesi Tenggara & 6.51 & 6.81 & -3.97 & -5.96 \\
\hline Maluku & 5.73 & 5.81 & -46.86 & -50.50 \\
\hline Maluku Utara & 5.77 & 7.67 & -21.45 & -20.14 \\
\hline
\end{tabular}

Sumber: Badan Pusat Statistik (diolah)

Salah satu sub komponen yang distribusinya relatif fluktuatif adalah net ekspor. Net ekspor merupakan selisih antara ekspor dan impor. Ekspor dan impor dalam hal ini termasuk ekspor impor luar negeri dan ekspor impor antar provinsi. Untuk memanfaatkan peluang ini, tentu harus mempertimbangkan potensi ekonomi masing-masing provinsi. Secara umum, potensi ekonomi ini dapat dilihat dari struktur PDRB Lapangan Usaha. Potensi ekonomi tercermin dari lapangan usaha yang mempunyai peranan terbesar. Tabel 3 menampilkan lapangan usaha unggulan di delapan provinsi kepulauan.

Tabel 3. Lapangan Usaha Unggulan Provinsi Kepulauan

\begin{tabular}{|c|c|c|}
\hline Provinsi (PDRB) & Lapangan Usaha & Share (\%) \\
\hline \multirow[t]{3}{*}{ Kep. Bangka Belitung } & Industri Pengolahan & 20.4 \\
\hline & Pertanian & 18.79 \\
\hline & Perdagangan & 15.56 \\
\hline \multirow[t]{3}{*}{ Kep. Riau } & Industri Pengolahan & 36.75 \\
\hline & Konstruksi & 18.02 \\
\hline & Pertambangan & 14.46 \\
\hline \multirow[t]{3}{*}{ Nusa Tenggara Barat } & Pertanian & 21.97 \\
\hline & Pertambangan & 19.45 \\
\hline & Perdagangan & 13.22 \\
\hline \multirow[t]{3}{*}{ Nusa Tenggara Timur } & Pertanian & 28.72 \\
\hline & Perdagangan & 11.05 \\
\hline & Administrasi Pemerintah & 12.83 \\
\hline \multirow[t]{3}{*}{ Sulawesi Utara } & Pertanian & 21.52 \\
\hline & Perdagangan & 12.13 \\
\hline & Konstruksi & 11.48 \\
\hline \multirow[t]{3}{*}{ Sulawesi Tenggara } & Pertanian & 24.08 \\
\hline & Pertambangan & 20.68 \\
\hline & Konstruksi & 13.35 \\
\hline \multirow[t]{3}{*}{ Maluku } & Pertanian & 23.58 \\
\hline & Administrasi Pemerintah & 20.17 \\
\hline & Perdagangan & 14.81 \\
\hline \multirow[t]{3}{*}{ Maluku Utara } & Pertanian & 23.95 \\
\hline & Perdagangan & 17.42 \\
\hline & Administrasi Pemerintah & 15.81 \\
\hline
\end{tabular}

Sumber: Badan Pusat Statistik (diolah) 
Untuk membangun pertumbuhan ekonomi di suatu daerah, tentu tidak cukup dengan hanya melihat potensi wilayah, tetapi juga dengan memperhatikan masalah utama yang muncul di daerah tersebut.

Tabel 4. Gini Ratio Provinsi Kepulauan 2013-2017

\begin{tabular}{|c|c|c|c|c|c|c|c|c|c|c|}
\hline \multirow{3}{*}{ Provinsi } & \multicolumn{10}{|c|}{ Gini Ratio } \\
\hline & \multicolumn{2}{|c|}{2013} & \multicolumn{2}{|c|}{2014} & \multicolumn{2}{|c|}{2015} & \multicolumn{2}{|c|}{2016} & \multicolumn{2}{|c|}{2017} \\
\hline & S1 & $\mathrm{S} 2$ & S1 & S2 & S1 & $\mathrm{S} 2$ & S1 & $\mathrm{S} 2$ & S1 & S2 \\
\hline Kep. Bangka Belitung & 0.313 & 0.307 & 0.303 & 0.295 & 0.283 & 0.275 & 0.275 & 0.288 & 0.282 & 0.276 \\
\hline Kep. Riau & 0.362 & 0.38 & 0.402 & 0.437 & 0.364 & 0.339 & 0.354 & 0.352 & 0.334 & 0.359 \\
\hline Nusa Tenggara Barat & 0.364 & 0.349 & 0.377 & 0.391 & 0.368 & 0.36 & 0.359 & 0.365 & 0.371 & 0.378 \\
\hline Nusa Tenggara Timur & 0.352 & 0.344 & 0.355 & 0.355 & 0.339 & 0.348 & 0.336 & 0.362 & 0.359 & 0.359 \\
\hline Sulawesi Utara & 0.422 & 0.446 & 0.424 & 0.436 & 0.368 & 0.366 & 0.386 & 0.379 & 0.396 & 0.394 \\
\hline Sulawesi Tenggara & 0.426 & 0.391 & 0.409 & 0.399 & 0.399 & 0.381 & 0.402 & 0.388 & 0.394 & 0.404 \\
\hline Maluku & 0.37 & 0.347 & 0.351 & 0.33 & 0.34 & 0.338 & 0.348 & 0.344 & 0.343 & 0.321 \\
\hline Maluku Utara & 0.318 & 0.32 & 0.325 & 0.322 & 0.28 & 0.286 & 0.286 & 0.309 & 0.317 & 0.33 \\
\hline Indonesia & 0.413 & 0.406 & 0.406 & 0.414 & 0.408 & 0.402 & 0.397 & 0.394 & 0.393 & 0.391 \\
\hline
\end{tabular}

Sumber: Badan Pusat Statistik (diolah)

Pada Tabel 4 dapat dilihat bahwa pada semester 2 tahun 2017 sebagian besar provinsi kepulauan mengalami peningkatan angka Gini Ratio, padahal secara umum angka Gini Ratio Indonesia menunjukkan penurunan nilai. Kenaikan ini menunjukkan bahwa terjadi peningkatan kesenjangan di sebagian besar Provinsi Kepulauan.

Fenomena sosial ekonomi lain dapat dilihat dari angka Indeks Pembangunan Manusia. Menurut UNDP, Indeks Pembangunan Manusia (IPM) mengukur capaian pembangunan manusia berbasis sejumlah komponen dasar kualitas hidup (Badan Pusat Statistik 2015). Salah satu manfaat IPM adalah mengukur keberhasilan dalam upaya membangun kualitas hidup manusia. Bila dilihat dari indikator ini, kualitas sumber daya manusia di Provinsi Kepulauan masih relatif rendah bila dibandingkan dengan rata-rata nasional.

Tabel 5. Indeks Pembangunan Manusia Provinsi Kepulauan 2013-2017

\begin{tabular}{|l|l|l|l|l|l|}
\hline \multirow{2}{*}{ Provinsi } & \multicolumn{5}{c|}{ Indeks Pembangunan Manusia } \\
\cline { 2 - 7 } & 2013 & 2014 & 2015 & 2016 & 2017 \\
\hline Kep. Bangka Belitung & 67.92 & 68.27 & 69.05 & 69.55 & 69.99 \\
\hline Kep. Riau & 73.02 & 73.4 & 73.75 & 73.99 & 74.45 \\
\hline Nusa Tenggara Barat & 63.76 & 64.31 & 65.19 & 65.81 & 66.58 \\
\hline Nusa Tenggara Timur & 61.68 & 62.26 & 62.67 & 63.13 & 63.73 \\
\hline Sulawesi Utara & 69.49 & 69.96 & 70.39 & 71.05 & 71.66 \\
\hline Sulawesi Tenggara & 67.55 & 68.07 & 68.75 & 69.31 & 69.86 \\
\hline Maluku & 66.09 & 66.74 & 67.05 & 67.6 & 68.19 \\
\hline Maluku Utara & 64.78 & 65.18 & 65.91 & 66.63 & 67.2 \\
\hline Indonesia & 68.31 & 68.9 & 69.55 & 70.18 & 70.81 \\
\hline Sumber: Badan Pusat Statistik (diolah) & & & & \\
\hline
\end{tabular}


Pada Tabel 5 dapat dilihat bahwa secara umum IPM di Provinsi Kepulauan, kecuali Kepulauan Riau dan Sulawesi Utara, lebih rendah dibandingkan rata-rata IPM nasional. Hal ini mengindikasikan bahwa kualitas hidup dan sumber daya manusia di provinsi kepulauan belum optimal.

Beberapa indikator-indikator sosial ekonomi secara umum memperlihatkan bahwa kondisi di Provinsi Kepulauan umumnya lebih tertinggal dibandingkan provinsi bukan berciri kepulauan. Bercermin dari beberapa permasalahan di atas, maka terdapat urgensi pemerataan sosial ekonomi di Provinsi Kepulauan.

\subsection{Apa yang harus dilakukan?}

\subsubsection{Evaluasi Faktor Produksi}

Peningkatan kesejahteraan sangat dipengaruhi dengan kegiatan ekonomi di suatu wilayah, berdasarkan analisis ketersediaan faktor produksi maka dapat dilihat ketersediaanya sebagai berikut.

Tabel 6. Analisis Ketersediaan Faktor Produksi

\begin{tabular}{|l|c|c|}
\multicolumn{1}{|c|}{ Faktor Produksi } & Provinsi Kepulauan & Provinsi Non Kepulauan \\
\hline Kualitas dan Kuantitas SDM & - & + \\
\hline Ketersediaan Lahan & + & + \\
\hline Bahan Baku & + & + \\
\hline Bahan Penolong & - & + \\
\hline Pemasaran & - & + \\
\hline
\end{tabular}

Sumber: Badan Pusat Statistik (diolah)

Jika dilihat dari sisi kualitas dan kuantitas sumber daya manusia, Provinsi Kepulauan memang memiliki nilai relatif lebih rendah dibanding wilayah lain di Indonesia. Selain nilai IPM yang relatif rendah, jumlah dan kepadatan penduduk di provinsi kepulauan juga cenderung lebih sedikit dibanding provinsi non kepulauan. Oleh karena itu, untuk mengembangkan perekonomian di wilayah ini, maka industri padat karya bukan merupakan solusi yang tepat karena terbatasnya jumlah penduduk. Jika industri yang dibangun adalah industri padat karya, maka terdapat kecenderungan industri akan lebih memilih menggunakan tenaga kerja dari luar (terkait kualitas dan kuantitas sumber daya manusia) sehingga tujuan percepatan pemerataan ekonomi tidak akan tercapai.

Faktor produksi selanjutnya adalah lahan. Meskipun pada umumnya Provinsi Kepulauan wilayahnya didominasi oleh perairan, namun karena kepadatan penduduknya relatif rendah, maka lahan yang tersedia diperkirakan akan cukup untuk membangun sumber ekonomi baru. Tersedianya lahan dan pemilihan komoditas yang memadai akan mendorong berkembangnya pusat-pusat ekonomi baru.

Provinsi Kepulauan identik dengan provinsi yang kaya akan sumber daya alam. Namun, sangat disayangkan bahwa sumber daya alam yang dijual ke luar wilayah sebagian besar masih dalam bentuk mentah. Terbatasnya bahan penolong dan industri pengolahan mengakibatkan nilai tambah yang diperoleh relatif lebih rendah daripada penjualan sumber daya alam yang telah diolah. Nilai tambah sebagian besar dinikmati oleh daerah pengolah yang umumnya terletak di luar provinsi kepulauan. Kendala lain yang juga dihadapi oleh Provinsi Kepulauan adalah masalah pemasaran. 
Kondisi geografis yang terpisah oleh perairan mengakibatkan sulitnya pengumpulan dan pemasaranproduk, terutamaproduktidaktahanlamasepertibuah-buahandansayur-sayuranyang biasanya menjadi produk utama kepulauan. Adanya fasilitas pengangkutan dan pemasaran yang memadai diharapkan mampu memicu pertumbuhan ekonomi baru di luar pulau-pulau utama.

Secara teoritis, kendala yang muncul akibat faktor geografis, seperti waktu dan biaya, dapat diatasi dengan adanya tol laut. Proses distribusi barang dari pusat produksi ke wilayahwilayah kepulauan sudah dipersingkat dan dipermurah dengan adanya tol laut. Akan tetapi, mengingat berbagai indikator yang ada, efektivitas dan efisiensi tol laut perlu dikaji lebih dalam.

Pengembangan potensi produksi wilayah tidak boleh didasari oleh tren komoditas ataupun bergantung pada kapasitas SDM saat ini, tetapi harus mengikuti rantai kebutuhan berdasarkan potensi Sumber Daya Alam. SDM dapat diubah namun kekayaan alam adalah karunia. Sejauh ini pengembangan produksi belum diikuti dengan riset value chain dan pemusatan produksi sesuai dengan SDA. Indonesia adalah salah satu negara dengan kekayaan alam terlengkap, namun masih melakukan impor untuk berbagai komoditas primer. Apakah permasalahannya pada SDA, SDM, Distribusi, atau Infrastruktur?

\subsubsection{Sudah Efisienkah Tol Laut?}

Menurut Bappenas, tol laut adalah Konektivitas laut yang efektif berupa adanya kapal yang melayari secara rutin dan terjadwal dari barat sampai ke timur Indonesia (Kementerian Perhubungan, 2017). Maksud dan tujuan program tol laut ini adalah untuk menjamin ketersediaan barang dan untuk mengurangi disparitas harga bagi masyarakat serta menjamin kelangsungan pelayanan penyelenggaraan angkutan barang ke daerah tertinggal, terpencil, terluar, dan perbatasan. Menurut data Kementerian Perhubungan tahun 2017, program tol laut ini memiliki 13 rute dan sudah menyinggahi 41 pelabuhan di seluruh Indonesia. Secara umum perbandingan biaya angkut menggunakan kapal Tol Laut mampu mengurangi biaya angkut mencapai 50\% dari biaya angkut kapal komersial. Dilihat dari penurunan harga berbagai komoditas, bila dibandingkan dengan tahun 2016, pada tahun 2017 di wilayahwilayah yang dilalui oleh tol laut, rata-rata komoditas mengalami penurunan harga sebesar 18 persen. Berikut ini adalah data yang diterbitkan oleh Kementerian Perhubungan (2017) yang bersumber dari data Kementerian Perdagangan pada tahun 2017: 
Tabel 7. Daftar Penurunan Harga Barang Kebutuhan Pokok Dan Penting Pada Daerah Yang Dilalui Jalur Tol Laut Antara Bulan Agustus 2016 Dengan Bulan April 2017

\begin{tabular}{|c|c|c|c|c|c|}
\hline No & Daerah & Jenis Komoditi & $\begin{array}{c}\text { Harga } \\
\text { Agustus } 2016\end{array}$ & $\begin{array}{c}\text { Harga } \\
\text { April } 2017\end{array}$ & $\begin{array}{c}\text { Penurunan } \\
(\%)\end{array}$ \\
\hline \multirow[t]{3}{*}{1} & Larantuka & Daging Ayam Ras & Rp. 65,385 & Rp. 45,000 & $-31 \%$ \\
\hline & & Tepung Terigu & Rp. 10,000 & Rp. 9,000 & $-10 \%$ \\
\hline & & Besi Beton $10 \mathrm{~mm}$ & Rp. 54,500 & Rp. 52,500 & $-4 \%$ \\
\hline 2 & Fak-Fak & Beras & Rp. 13,000 & Rp. $\quad 10,000$ & $-23 \%$ \\
\hline \multirow[t]{4}{*}{3} & Kaimana & Beras & Rp. 12,000 & Rp. 11,000 & $-8 \%$ \\
\hline & & Gula Pasir & Rp. 15,000 & Rp. 13,000 & $-13 \%$ \\
\hline & & Telur Ayam Ras & Rp. 60,000 & Rp. 26,667 & $-56 \%$ \\
\hline & & Semen Gresik & Rp. 81,250 & Rp. 65,000 & $-20 \%$ \\
\hline \multirow[t]{2}{*}{4} & Natuna & Beras & Rp. $\quad 14,000$ & Rp. 12,500 & $-11 \%$ \\
\hline & & Gula Pasir & Rp. $\quad 17,000$ & Rp. 14,000 & $-18 \%$ \\
\hline \multirow[t]{9}{*}{5} & Sabu & Gula Pasir & Rp. 15,000 & Rp. 13,000 & $-13 \%$ \\
\hline & & Minyak Goreng Kemasan & Rp. 17,000 & Rp. 15,500 & $-9 \%$ \\
\hline & & Tepung Terigu & Rp. 13,000 & Rp. 7,000 & $-46 \%$ \\
\hline & & Besi Beton $6 \mathrm{~mm}$ & Rp. 40,000 & Rp. 27,500 & $-31 \%$ \\
\hline & & Besi Beton $8 \mathrm{~mm}$ & Rp. 60,000 & Rp. 39,000 & $-35 \%$ \\
\hline & & Bes Beton $10 \mathrm{~mm}$ & Rp. 80,000 & Rp. 65,000 & $-19 \%$ \\
\hline & & Besi Beton $12 \mathrm{~mm}$ & Rp. 115,000 & Rp. 82,500 & $-28 \%$ \\
\hline & & Triplek $3 \mathrm{~mm}$ & Rp. 65,000 & Rp. 50,000 & $-23 \%$ \\
\hline & & Triplek $6 \mathrm{~mm}$ & Rp. 100,000 & Rp. 89,000 & $-11 \%$ \\
\hline \multirow[t]{4}{*}{6} & $\begin{array}{l}\text { Kep. Aru } \\
\text { (Dobo) }\end{array}$ & Gula Pasir & Rp. $\quad 18,750$ & Rp. 15,000 & $-20 \%$ \\
\hline & & Minyak Goreng Kemasan & Rp. 17,938 & Rp. 16,000 & $-11 \%$ \\
\hline & & Telur Ayam Ras & Rp. 53,750 & Rp. 52,500 & $-2 \%$ \\
\hline & & Tepung Terigu & Rp. 12,000 & Rp. 10,000 & $-17 \%$ \\
\hline \multirow[t]{5}{*}{7} & Moa & Beras & Rp. $\quad 14,500$ & Rp. 11,500 & $-21 \%$ \\
\hline & & Telur Ayam Ras & Rp. 40,000 & Rp. 32,000 & $-20 \%$ \\
\hline & & Besi Beton $6 \mathrm{~mm}$ & Rp. 45,000 & Rp. 35,000 & $-22 \%$ \\
\hline & & Besi Beton $8 \mathrm{~mm}$ & Rp. 65,000 & Rp. 55,000 & $-15 \%$ \\
\hline & & Besi Beton $12 \mathrm{~mm}$ & Rp. 85,000 & Rp. 75,000 & $-12 \%$ \\
\hline
\end{tabular}

Sumber: Badan Pusat Statistik (diolah) 
Di sisi lain, meskipun telah mampu menurunkan biaya angkut barang dan harga komoditas, namun keberadaan tol laut belum mampu mengoptimalkan perekonomian di Provinsi Kepulauan. Hal ini terjadi karena belum optimalnya muatan kapal, khususnya muatan balik. Data Kementerian Perhubungan (2017) menunjukkan bahwa pada sebagian besar rute muatan balik terisi sangat sedikit, bahkan seringkali kosong. Keterbatasan komoditi di pulau utama serta terbatasnya alat bongkar muat disinyalir menjadi penyebab masalah ini.

Selain itu, karena hanya menjangkau pelabuhan yang relatif besar, maka manfaat program tol laut ini belum dirasakan oleh masyarakat luas, utamanya masyarakat yang tinggal di pulau-pulau yang terpisah dari pelabuhan besar. Belum tersedianya angkutan barang rutin untuk mengangkut hasil produksi dari pulau kecil ke pulau utama mengakibatkan dampak tol laut belum dapat dirasakan oleh masyarakat luas.

Dari uraian di atas, dapat disimpulkan terdapat beberapa kendala optimalisasi program tol laut, antara lain:

- Tol laut hanya untuk komoditas tertentu

- Saat ini tol laut hanya mendistribusikan barang ke daerah, belum efektif membawa barang dari daerah

- Tol laut hanya dapat menjangkau pelabuhan utama, sedangkan produksi tersebar di semua wilayah

- Kapasitas produksi daerah yang kecil dan tersebar belum dapat dijangkau oleh tol laut

Untuk mengatasi kendala-kendala yang ada, penelitian ini mencoba memformulasikan suatu program yang disebut dengan "Infrastructure Sharing". Program ini diinspirasi oleh Infrastructure Sharing yang diterapkan di bidang teknologi informasi. Program "Infrastructure Sharing" di bidang sosial ekonomi ini akan melibatkan banyak pihak sehingga sense of belonging terhadap program ini lebih terasa. Diharapkan pula manfaatnya akan dirasakan oleh seluruh lapisan masyarakat sehingga dapat mempercepat pemerataan ekonomi utamanya di Provinsi Kepulauan.

\subsubsection{Apakah yang dimaksud Infrastructure Sharing}

Secara umum, Infrastructure Sharing dapat diartikan sebagai pembangunan suatu fasilitas yang digunakan oleh lebih dari satu instansi atau lebih dari satu tujuan. Dalam dunia teknologi informasi, Infrastructure Sharing merupakan salah satu tren untuk dalam menyebarkan jaringan internet. Di negara-negara berkembang terdapat kecenderungan bagi pemerintah untuk mendukung proyek-proyek Infrastructure Sharing sebagai cara untuk mengurangi biaya dalam penyebaran jaringan, memperluas cakupan, mengurangi kesenjangan digital pedesaan-perkotaan, dan mempercepat pengambilan broadband (Garcia dan Kelly 2015). Terinspirasi dari penerapan Infrastructure Sharing di bidang ini, maka penulis mencoba membuat formulasi Infrastructure Sharing untuk diterapkan dalam bidang sosial ekonomi.

Tujuan utama Infrastructure Sharing adalah mengurangi biaya produksi, menumbuhkan kesempatan berusaha, dan mengurangi biaya investasi pembangunan infrastruktur sehingga pemanfaatannya efektif dan efisien. Beberapa infrastruktur telah dirintis dan telah terbangun, namun dirasakan belum tepat guna sehingga belum meningkatkan produksi sektor primer dan kesempatan memulai atau mengembangkan usaha. 
Pembangunan infrastruktur sharing yang telah dibangun belakangan ini salah satunya adalah program tol laut, namun perlu juga diikuti pembangunan program Infrastructure Sharing di bidang sosial ekonomi lainnya dengan melibatkan berbagai pihak, seperti:

1. Pelayaran perintis, untuk menjangkau pulau-pulau yang tak disinggahi tol laut,

2. BUMN (terutama Bulog), dengan optimalisasi program "Rumah Kita", serta modernisasi pengepulan hasil produksi dengan menggunakan aplikasi internet (internet of things),

3. Pos Indonesia, mendukung BUMN/Bulog dalam proses pengepulan hasil produksi dan sebagai pihak perantara intermediasi keuangan,

4. Pemerintah Daerah, sebagai regulator dan katalisator program.

Agar program ini berjalan sesuai dengan yang diharapkan, maka terlebih dahulu dilakukan kajian pemetaan potensi daerah agar tipologi program yang akan dilakukan sesuai dengan karakteristik daerah yang bersangkutan. Pemetaan potensi daerah yang bersifat menyeluruh dapat menggunakan berbagai data komprehensif, salah satunya adalah data Potensi Desa 2014.

Bagian selanjutnya dari program ini akan menguraikan peranan pihak-pihak utama yang terlibat dalam program Infrastructure Sharing serta simulasi Infrastructure Sharing yang bisa dilakukan.

\section{A. Tol Laut dan Pelayaran Perintis}

Kondisi geografis Provinsi Kepulauan membutuhkan sarana konektivitas antar pulau yang cepat dan efisien untuk mempercepat pemerataan ekonomi. Dalam rangka pengembangan konektivitas antar pulau, salah satu sarana yang selama ini digadang-gadang menjadi solusi adalah pelayaran perintis yang dapat menjangkau sampai pulau-pulau kecil. Pelayaran perintis mempunyai peran penting karena tidak semua pulau dapat dijangkau oleh kapal tol laut. Menurut Kamus Besar Bahasa Indonesia, pelayaran perintis adalah kapal yang merintis suatu tugas (misalnya menghubungi daerah terpencil yang belum terbuka). Penyelenggaraan pelayaran perintis bertujuan untuk mendorong pengembangan daerah, meningkatkan konektivitas antar pulau dan pemerataan pembangunan serta hasil-hasilnya demi terwujudnya stabilitas nasional yang mantap dan dinamis dalam kerangka Negara Kesatuan Republik Indonesia. Pada tahun 2017, pelayaran perintis melayani 96 rute dan akan meningkat menjadi 113 rute di tahun 2018 (Dirjen Perhubungan Laut 2017).

Selama ini, pelayaran perintis cenderung hanya mengangkut penumpang, belum dimanfaatkan optimal untuk mengangkut hasil produksi dari pulau-pulau kecil ke pulau utama. Dalam program Infrastructure Sharing, pelayaran perintis akan menjadi mata rantai penghubung antara pulau kecil dengan program tol laut. Pelayaran perintis diupayakan diarahkan untuk mengangkut hasil-hasil produksi tertentu dari pulau-pulau pengumpan ke pulau atau pelabuhan utama sehingga dapat diangkut oleh kapal tol laut. Dalam hal ini, pelayaran perintis akan berfungsi sebagai feeder untuk kapal tol laut. Pengembangan koneksi pelayaran perintis dan tol laut di beberapa pulau yang selama ini belum terbuka akan membuat distribusi barang dan pergerakan masyarakat semakin ramai.

Optimalisasi konektivitas pelayaran perintis dan tol laut akan membawa manfaat ganda. Tidak hanya untuk meningkatkan efektivitas dan efisiensi distribusi barang ke pulau, mengurangi ketimpangan harga, tetapi juga akan meningkatkan pendapatan masyarakat di 
pulau kecil dengan terbukanya pasar baru untuk produk-produk lokal unggulan.

\section{B. Tol Laut dan Bulog, BUMD, dan Koperasi Produksi}

Untuk meningkatkan efisiensi pengumpulan hasil produksi dari pulau-pulau kecil sebelum diangkut dengan pelayaran perintis, diperlukan suatu fasilitas untuk mewadahi pengumpulan produksi dari masyarakat. Setelah diadakan pemetaan potensi daerah, masyarakat dapat diarahkan untuk memproduksi produk unggulan sesuai dengan potensi dan karakteristik daerah. Produk yang dihasilkan oleh perseorangan tentu tidak akan efisien apabila langsung diangkut oleh kapal perintis menuju pelabuhan utama. Selain tidak efisien dari segi biaya, pengangkutan produk perseorangan dalam jumlah kecil tentu tidak akan memberikan dampak yang komprehensif terhadap perekonomian wilayah. Oleh karena itu, diperlukan fasilitas/fasilitator yang berperan sebagai pengepul dan gudang produk sebelum dipasarkan ke luar pulau.

Salah satu program yang sudah dilakukan oleh pemerintah adalah program "Rumah Kita”. Program ini merupakan tindak lanjut pembangunan sentra logistik sebagaimana diatur dalam Peraturan Presiden Republik Indonesia Nomor 70 Tahun 2017 tentang Penyelenggaraan Kewajiban Pelayanan Publik untuk Angkutan Barang dari dan ke Daerah Tertinggal, Terpencil, Terluar, dan Perbatasan. Terdapat beberapa titik "Rumah Kita” yang telah telah dibuat, di antaranya adalah Nias, Mentawai, Natuna, Sanggate, Dompu, Waingapu, Rote, Kalabahi, Tahuna, Saumlaki, Manokwari, dan Timika. Titik-titik ini semuanya berada di pelabuhan yang disinggahi langsung oleh kapal tol laut, belum menjangkau pulau-pulau kecil yang tidak dilintasi oleh tol laut.

Oleh karena itu, di pulau-pulau yang bukan merupakan pulau utama juga sebaiknya dibangun sentra logistik yang berfungsi sebagai tempat pengepul hasil produksi. Sentra logistik ini dapat dibangun oleh Bulog (jika komoditas sesuai), BUMD, atau koperasi produksi. Sentra logistik ini diharapkan tidak hanya berperan sebagai pembeli dari barangbarang yang diproduksi di wilayah-wilayah, tetapi juga menjadi fasilitator edukasi untuk meningkatkan kemampuan produksi dan kemampuan sumber daya masyarakat setempat. Produsen perseorangan dapat menjual produknya langsung ke sentra logistik ini. Hal ini akan memperpendek mata rantai perdagangan sehingga keuntungan yang diterima oleh produsen diharapkan semakin besar. Jika menurut analisis pemetaan potensi daerah, suatu wilayah di pulau pengumpan yang areanya relatif luas dapat dijadikan sentra produksi suatu komoditas tertentu, maka dengan bekerja sama dengan Pemda, Bulog dapat langsung datang ke daerah-daerah potensial untuk membeli langsung dari petani/produsen.

Fungsi pengelola sentra logistik sebagai fasilitator edukasi masyarakat juga tak kalah penting dilakukan. Produksi komoditas unggulan yang berkelanjutan memerlukan sumber daya manusia yang terlatih. Oleh karena itu, pelatihan yang difasilitasi oleh pengelola sentra logistik bekerja sama dengan berbagai pihak perlu dilakukan. Selain itu, pemanfaatan teknologi juga tidak boleh ditinggalkan. Pemanfaatan internet untuk mengetahui harga, jumlah penawaran produk, serta jumlah permintaan konsumen merupakan langkah-langkah sederhana untuk mendekatkan masyarakat dengan kesejahteraan melalui pemanfaatan teknologi. 


\section{Optimalisasi PT Pos Indonesia}

Tidak seperti perusahaan jasa kurir swasta, layanan PT. Pos Indonesia menjangkau wilayah terkecil di Indonesia hingga ke pelosok-pelosok daerah. Keunggulan ini dapat dimanfaatkan untuk mendukung program Infrastructure Sharing di bidang pemasaran produk. Apabila opsi fasilitas untuk mewadahi pengumpulan produksi dari masyarakat tidak dapat menjangkau wilayah produksi, maka opsi pengiriman produk melalui pos dapat dijadikan sebagai alternatif. Untuk meringankan beban produsen, maka pengelola sentra logistik dan Pemda setempat dapat membuat suatu kesepakatan dengan PT. Pos untuk subsidi atau pembebasan ongkos kirim komoditas-komoditas tertentu sesuai dengan produk unggulan wilayah.

Selain sebagai jasa kurir, PT. Pos Indonesia juga dapat menjadi fasilitator keuangan. Salah satu fitur yang dapat dikembangkan adalah pemanfaatan Pospay. Pospay adalah suatu pelayanan pembayaran kantorpos mudah, lebih dekat, lebih cepat, dan aman karena menggunakan Sistem Online Payment Point (SOPP) yang telah menjangkau hingga 4.800 jaringan kantorpos di seluruh Indonesia dan di 40.000 Agenpos yang akan terus dikembangkan menyesuaikan dengan kebutuhan dan harapan masyarakat (Pos Indonesia, 2018). Di samping itu, Pos dapat berperan dalam edukasi finasial khususnya untuk petanipetani di wilayah terpencil serta sebagai fasilitator jaminan transaksi finansial bila tidak tersedia bank di wilayah bersangkutan.

\section{Pemerintah Daerah sebagai Katalisator dan Regulator}

Pemerintah Daerah tentu saja merupakan aspek yang tidak dapat dikesampingkan dalam proses kemajuan suatu daerah. Dalam program Infrastructure Sharing ini, pemerintah daerah berperan sebagai katalisator dan regulator.

Dalam perannya sebagai katalisator, selain pihak-pihak yang telah disebutkan di uraian sebelumnya (pelayaran perintis, BUMN/BUMD, dan Pos), pemerintah daerah juga turut berperan untuk menghubungkan pulau-pulau kecil dengan pelabuhan utama yang dilalui oleh tol laut. Bersama dengan pihak-pihak lain Pemda mengumpulkan barang produksi dari wilayah-wilayah yang tidak terjangkau tol laut melalui berbagai cara. Salah satu cara yang dapat ditempuh adalah optimalisasi dan dukungan pada pelayaran rakyat untuk menghubungkan wilayah-wilayah yang tidak dapat diakses tol laut bila rute pelayaran perintis belum tersedia. Selain itu, pemerintah daerah juga dapat melakukan kajian mendalam tentang potensi daerah agar produksi yang dihasilkan semakin berkualitas. Kajian ini dalam dilakukan dengan sinergi antara Bappeda, BPS, serta dinas lain yang terkait. Kajian pemetaan potensi daerah dapat dijadikan dasar pembentukan special supply chain atau sentra produksi khusus untuk memenuhi kebutuhan dalam negeri berdasarkan potensi wilayah.

Fungsi utama pemerintah daerah sebagai regulator juga memegang peranan penting dalam program ini. Sebagai regulator, pemerintah dapat membuat peraturan untuk mencegah terjadinya monopoli, terutama apabila partner program Infrastructure Sharing merupakan pihak swasta. Pemerintah daerah juga berkewajiban memastikan semua pihak yang terlibat dalam program ini senantiasa berkoordinasi sehingga tidak terdapat penumpukan barang di suatu tempat atau kekurangan supply karena masalah produksi dan pengangkutan di wilayah tertentu. 


\section{E. Pemetaan Potensi Daerah}

Secara geografis, setiap wilayah mempunyai karakteristik yang berbeda. Karakteristik tersebut mengakibatkan setiap wilayah memiliki potensi yang berbeda. Untuk mengetahui potensi setiap wilayah, diperlukan pemetaan potensi wilayah yang meliputi kegiatan identifikasi, inventarisasi, dan zonasi (Romadhon dan Sucipto 2010). Salah satu data yang dapat digunakan sebagai bahan identifikasi awal adalah data Podes yang dihasilkan oleh BPS. Podes menyajikan data potensi desa/kelurahan, sebagai bahan penyusunan statistik wilayah kecil, penyusunan berbagai analisis dan kebijakan terkait kewilayahan, dan sebagai penghitungan indikator-indikator pembangunan/kemajuan desa (Badan Pusat Statistik 2018). Pengumpulan data Podes dilakukan sebanyak 3 (tiga) kali dalam kurun waktu 10 tahun, sebagai bagian dari rangkaian kegiatan Sensus Penduduk, Sensus Pertanian dan Sensus Ekonomi.

Podes tidak hanya menyajikan identifikasi komoditas unggulan, tetapi juga menyajikan data identifikasi sumber daya manusia, kondisi lahan, serta potensi keunggulan serta kewaspadaan terkait wilayah geografis. Selanjutnya, data hasil identifikasi dari Podes ini dapat digunakan sebagai input untuk inventarisasi pemetaan komoditas unggulan suatu wilayah, peluang, serta tantangan yang mungkin dihadapi. Inventarisasi komoditas unggulan akan disesuaikan dengan kondisi geografis serta sumber daya manusia yang tersedia. Pada tahap ini juga dilakukan identifikasi permasalahan faktor penentu teknis pengembangan komoditas.

Tahap selanjutnya adalah zonasi atau pembangunan zona kawasan komoditas tertentu. Pembangunan zona kawasan disusun dan dibuat untuk menjadi dasar bagi pengembangan komoditi unggulan yang telah teridentifikasi. Zona kawasan ini yang akan menjadi cikal bakal sentra produksi. Seperti yang telah dipaparkan di bagian sebelumnya, produksi komoditas tidak harus dilaksanakan secara masif di area yang luas. Produksi dapat dilakukan dalam ukuran kecil di setiap lahan yang dimiliki oleh rumah tangga. Proses pemasaran yang akan dilakukan secara masif setelah produk dihasilkan.

Pemetaan potensi desa ini merupakan salah satu langkah awal untuk meningkatkan perekonomian masyarakat. Kerja sama semua pihak yang terlibat dibutuhkan untuk menjaga produksi yang berkelanjutan sehingga percepatan pemerataan ekonomi dapat segera dirasakan.

\section{F. Simulasi Pemanfaatan Infrastructure Sharing}

Saat ini produksi barang dan jasa di wilayah kepulauan sulit memenuhi jumlah yang memiliki nilai keekonomian karena jumlah produksi yang terbatas mengingat besarnya biaya produksi dan pemasaran. Melalui Infrastructure Sharing maka produksi dapat dilakukan dalam jumlah kecil, tetapi dilakukan secara kolektif sehingga memberikan manfaat ekonomi yang dapat meningkatkan kesejahteraan.

Adanya penambahan pendapatan dapat menstimulasi penduduk untuk meningkatkan laba usaha. Peningkatan laba usaha dapat mendorong kemauan untuk memajukan usaha dengan cara yang lebih efektif dan efisien. Usaha besar akan menambah jumlah lapangan usaha, sehingga menurunkan pengangguran.

Bagian ini akan menampilkan dua jenis simulasi Infrastructure Sharing. Simulasi pertama adalah sebuah simulasi sederhana dengan memanfaatkan kondisi yang sudah 
tersedia (default condition). Simulasi kedua adalah simulasi dengan memanfaatkan identifikasi data Podes dengan memanfaatkan kondisi yang sudah tersedia (default condition) ditambah dengan pemanfaatan potensi baru.

Kedua simulasi ini mempunyai tahap kegiatan yang sama, sebagaimana diuraikan pada gambar berikut.

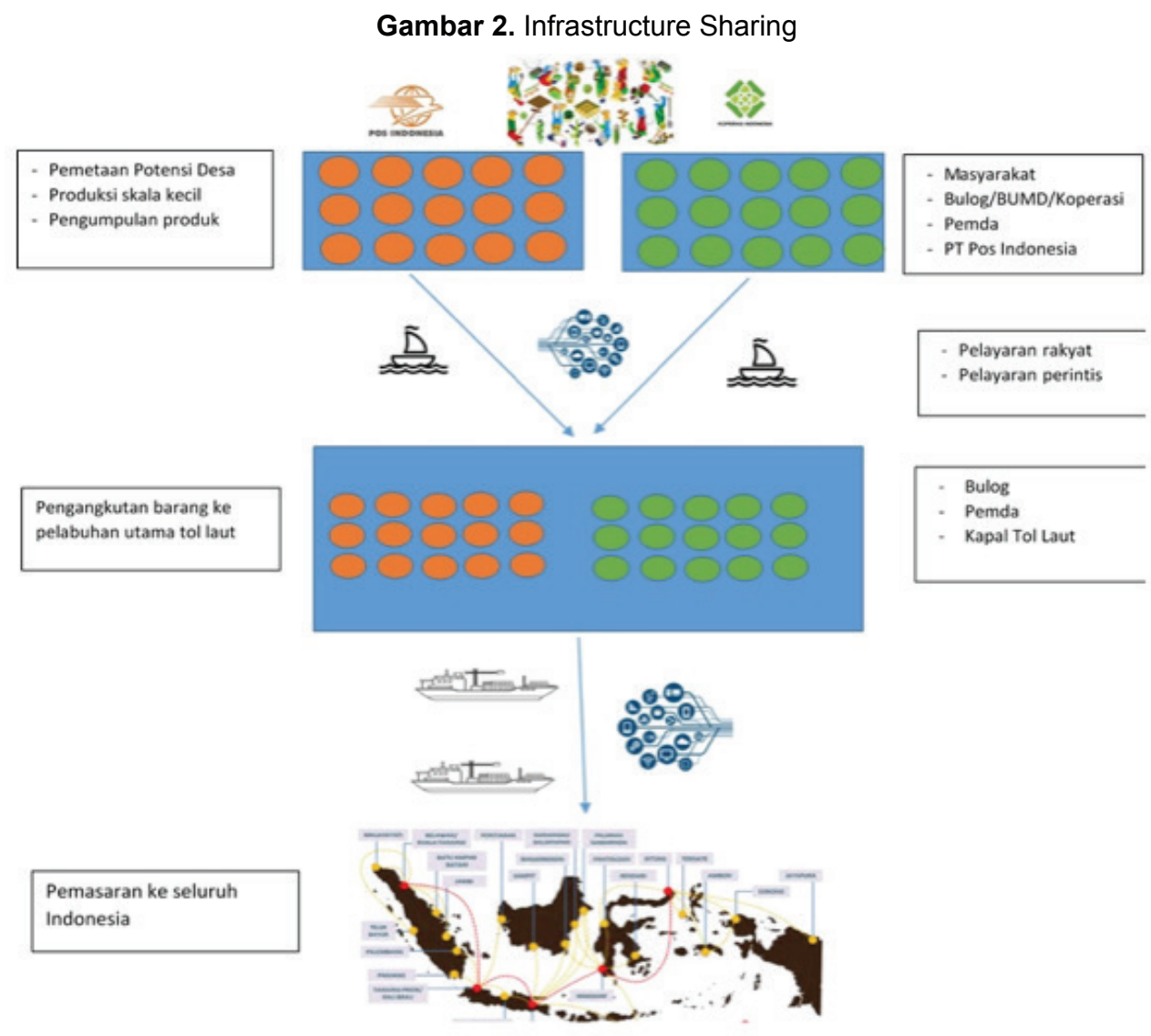

\section{Simulasi I:}

Target utama program ini adalah petani gurem di Provinsi Kepulauan yang berjumlah sekitar 922 ribu rumah tangga.

Misalkan suatu desa yang memiliki potensi untuk penanaman cabai terdiri dari $100 \mathrm{KK}$. Jika setiap KK di desa tersebut memiliki lahan kosong $50 \mathrm{~m} 2$ dan produktivitas cabai sebesar $5 \mathrm{~kg} /$ bulan, maka jumlah cabai yang dihasilkan dalam satu desa per bulan adalah sebesar $500 \mathrm{~kg}$. Dengan asumsi harga cabai Rp 20.000/kg, maka setiap KK akan mendapat tambahan pendapatan bruto sebesar Rp 100.000/bulan.

Dengan asumsi bahwa sebuah kecamatan terdiri dari 10 desa, maka jumlah produksi cabai di kecamatan tersebut menjadi 5 ton. Pemerintah dan Bulog dapat menjemput produksi cabai ini dengan harga transportasi yang wajar. Karena cabai merupakan komoditas yang usia penyimpanannya pendek, maka bisa dilakukan pengolahan sederhana seperti olah cabai kering atau olah cabai giling sebelum dikirimkan/dikumpulkan oleh pemerintah.

Bila sentra produksi ini terletak bukan di pulau utama, maka kapal perintis atau pelayaran rakyat akan mengangkut olahan cabai ini menuju pulau utama yang disinggahi oleh tol laut. Pengangkutan olahan cabai secara masif, sekitar lima ton, secara rutin tentu akan lebih efisien dibandingkan pengangkutan dalam jumlah kecil. 
Selanjutnya, dengan menggunakan fasilitas tol laut, olahan cabai ini dapat dipasarkan keluar wilayah

Untuk kesinambungan produksi serta menjaga kualitas produk, maka pemerintah dapat bekerja sama dengan BUMN/BUMD serta akademisi untuk melakukan pembinaan rutin.

Untuk menunjang permodalan, pemerintah dapat bekerja sama dengan koperasi untuk menfasilitasi permodalan tanpa bunga atau dengan bunga lunak. Pemanfaatan PT Pos sebagai perantara transaksi finansial juga dapat dilakukan karena PT POS menjangkau hingga ke pelosok. Selain mempermudah masyarakat, langkah ini juga dapat menyehatkan PT Pos yang mulai melesu karena core bussines perusahaan ini perlahan tergerus teknologi informasi. Fasilitas PT Pos di bidang jasa keuangan dapat dimanfaatkan dalam hal ini.

\section{Simulasi II:}

Tahap Identifikasi Potensi Desa, simulasi ini memanfaatkan data Podes 2014 di suatu Provinsi Kepulauan. Ada beberapa variabel yang diambil dari Podes 2014, antara lain:

- Variabel desa yang berbatasan langsung dengan laut

- Sumber penghasilan utama penduduk dan komoditas pertanian yang dihasilkan

- Akses jalan ke sentra produksi

- Pemanfaatan sungai, saluran irigasi, danau/situ/bendungan

- Jenis keterampilan yang dimiliki oleh penduduk

- Keberadaan BTS dan sinyal telepon seluler

- Keberadaan kantor pos dan jasa kurir swasta

- Keberadaan industri mikro

- Keberadaan koperasi, bank, dan fasilitas kredit

- Program pemberdayaan masyarakat

- Variabel terkait geografis dan mitigasi bencana

Tahap Inventarisasi, dibedakan menjadi tiga jenis menurut sektor unggulan wilayah, yaitu wilayah sektor primer, wilayah sektor sekunder, dan wilayah sektor tersier. Untuk wilayah sektor primer, inventarisasi komoditas unggulan dapat dilakukan dengan inventarisasi komoditas berdasarkan kondisi tanah dan ketinggian wilayah. Untuk wilayah sektor sekunder dan tersier, inventarisasi dapat dilakukan dengan pemetaan sektor unggulan dipadukan dengan kuantitas dan kualitas sumber daya manusia serta keberadaan program pemberdayaan masyarakat. Selain itu, pada tahap itu, pertimbangan faktor teknis seperti akses jalan, teknologi informasi, serta faktor pendukung lain wajib dipertimbangkan

Pembangunan zona kawasan tidak hanya mempertimbangkan hasil identifikasi dan inventarisasi, tetapi juga mempertimbangkan potensi masalah yang muncul di kawasan tersebut. Untuk memudahkan rencana pembangunan zona kawasan setelah tahap identifikasi dan inventarisasi, dapat dibuat tabel bantu seperti Tabel 8 berikut ini:

Tabel 8.. Rencana dan Rekomendasi Pembangunan Zona Kawasan

\begin{tabular}{|l|l|l|l|l|l|}
\hline No & Jenis Potensi & Komoditas & Lokasi & $\begin{array}{l}\text { Rencana Pengembangan Zona } \\
\text { Kawasan }\end{array}$ & $\begin{array}{l}\text { Masalah yang } \\
\text { mungkin muncul }\end{array}$ \\
\hline 1 & & & & & \\
\hline 2 & & & & & \\
\hline
\end{tabular}


Setelah tahap pemetaan potensi desa dilakukan, selanjutnya pemerintah daerah bekerja sama dengan berbagai pihak dapat mulai berinvestasi pada pembentukan sentra produksi. Jika infrastruktur untuk pembentukan sentra produksi belum tersedia, maka dapat dimulai dengan penyediaan infrastruktur yang mendukung meskipun kondisinya belum optimal. Produksi komoditas diarahkan agar waktu produksi dan kualitas produksi yang dihasilkan relatif homogen dan dapat tersedia secara berkesinambungan. Hal ini menjadi penting untuk efektivitas dan efisiensi pada tahapan selanjutnya.

Bila pada simulasi I, produk yang diproduksi adalah produk yang sudah ada saja, maka pada simulasi ini, produksi diarahkan juga menyentuh komoditas baru. Komoditas alternatif ini diperoleh dari hasil pemetaan potensi desa dan sangat mungkin mempunyai sektor yang berbeda dengan sektor unggulan pertama. Misal suatu wilayah menjadi sentra produksi padi, juga memungkinkan mengembangkan sektor tersier berupa agrowisata.

Sama halnya dengan Simulasi I, karena produksi bisa dilakukan dalam skala kecil, maka sebelum dilakukan pemasaran keluar wilayah, produk terlebih dahulu dikumpulkan oleh BUMN/BUMD/Koperasi. Pengiriman ke pelabuhan di pulau utama bisa dilakukan dengan fasilitas pelayaran perintis atau pelayaran rakyat.

Bantuan finansial kadang dibutuhkan oleh produsen. Oleh karena itu, peran pemerintah, koperasi, dan lembaga intermediasi keuangan lainnya sangat penting. Pembinaan sumber daya manusia juga merupakan hal mutlak untuk menjaga kualitas dan kesinambungan produksi, baik produksi barang maupun jasa. Karena pada Simulasi II ini juga melibatkan sektor baru yang potensial, maka simulasi ini memerlukan pembinaan yang lebih dalam dibandingkan dengan Simulasi I.

\section{Kesimpulan}

1. Secara sosial ekonomi, Provinsi Kepulauan cenderung lebih tertinggal daripada provinsi non kepulauan

2. Salah satu penyebabnya adalah kendala geografis

3. Program Tol laut yang sudah ada perlu dioptimasilasi

4. Diperlukan kebijakan tambahan untuk menstimulasi perkembangan ekonomi dan kesejahteraan

5. Peran dan dukungan Pemda, Bulog, BUMD, Pos, dan koperasi mutlak diperlukan

\section{Daftar Pustaka}

Badan Pusat Statistik. 2015. Indeks Pembangunan Manusia 2014 Metode Baru. Jakarta: Badan Pusat Statistik.

-. 2018. Sihumas. 11 Januari. Diakses Juni 14, 2018. https://sihumas.bps.go.id/generate_ berita.php?id=33.

Bappenas. 2017. Arah Pengembangan Provinsi Kepulauan . Jatinangor: Bappenas.

Detik.com. 2017. Detik.com. 17 Oktober. https://finance.detik.com/berita-ekonomibisnis/d-3687690/masalah-kapal-tol-laut-banyak-muatan-kosong-pas-balik-kejawa.

Dirjen Perhubungan Laut. 2017. Dirjen Perhubungan Laut. 3 OKtober. http://hubla.dephub. go.id/berita/Pages/PELAYARAN-PERINTIS-DUKUNG-KONEKTIVITAS- 


\section{ANTAR-PULAU-DI-INDONESIA.aspx.}

Garcia, Jose Marino, dan Tim Kelly. 2015. "The Economics and Policy Implications of InfrastructureSharing and Mutualisation in Africa." Dalam World Development Report 2016, oleh World Bank. Washington: World Bank.

Kementerian Perhubungan. 2017. Pelaksanaan Penyelenggaraan Angkutan Barang di Laut (Tol Laut). Jakarta: Kementerian Perhubungan.

Kuahaty, Yusuf. 2017. “Timor Express.” Timor Express. 17 Oktober. Diakses April 12, 2018. http://timorexpress.fajar.co.id/2017/10/17/problematika-dan-solusi-provinsikepulauan-atau-berciri-kepulauan/.

Pos Indonesia. 2018. PT Pos Indonesia. 13 Juni. http://www.posindonesia.co.id/index.php/ pospay/.

Republik Indonesia. 2014. Undang-Undang No. 23 Tahun 2014 Tentang Pemerintah Daerah. Lembaran Negara Republik Indonesia Tahun 2014, Nomor 244. Sekretariat Negara. Jakarta.

Republik Indonesia. 2017. Peraturan Presiden Republik Indonesia Nomor 70 tentang Penyelenggaraan Kewajiban Pelayanan Publik untuk Angkutan Barang dari dan ke Daerah Tertinggal, Terpencil, Terluar, dan Perbatasan. Sekretariat Kabinet RI. Jakarta.

Romadhon, Agus, dan Sucipto. 2010. "Pemetaan Potensi Komoditas dan Rancangan Pengembangan di Kecamatan Blega, Bangkalan Madura.” Agrovigor 3 Nomor 2: 146156. 